\title{
Obraz odzyskany. Fotograficzne portrety ocalonych
}

\author{
Prolog: fotografie identyfikacyjne
}

„Tym, co SS-mani chcieli zniszczyć w Auschwitz, było nie tylko życie, ale także [...] sam kształt człowieka i jego obraz wraz z nim”.

Georges Didi-Huberman ${ }^{1}$

Ludzie ubrani w pasiaki, obozowe uniformy, to - obok bramy obozu Auschwitz - jedna z ikon Zagłady. Skutecznie utrwalona przez filmy fabularne, wielokrotnie eksploatowana w sztuce, swoje źródło ma jednak w fotografii archiwalnej. To zarówno zdjęcia zrobione przez aliantów po wejściu do obozów w 1945 r., jak i zdjęcia identyfikacyjne, wykonywane wybranym więźniom i więźniarkom w Auschwitz², sprawiły, że pasiak stał się tak powszechnym i oczywistym znakiem.

Potrójne, „więzienne” fotografie (profil, en face, ujęcie trzy czwarte), które wykonywano w obozie Auschwitz I w latach 1941-1943 przez jednostkę o nazwie Erkennungdienst, powstawały w studio fotograficznym znajdującym się w bloku 26., obsługiwanym głównie przez wyspecjalizowanych więźniów³. Częściowo przez nich uratowane podczas pospiesznej ewakuacji obozu ${ }^{4}$, są obecnie używane nie tyl-

\footnotetext{
${ }^{1}$ Georges Didi-Huberman, Obrazy mimo wszystko, tłum. Mai Kubiak Ho-Chi, Kraków: Universitas, 2008, s. 66.

${ }^{2}$ Archiwum Państwowego Muzeum Auschwitz-Birkenau (dalej APMAB), Oświadczenia, t. 125, Relacja Wilhelma Brassego z 1 IX 1989 r., k. 50, oraz Tadeusz Iwaszko, Deportacja do obozu, rejestracja więźniów [w:] Auschwitz. Nazistowski obóz śmierci, red. Franciszek Piper, Teresa Świebocka, Oświęcim: Wydawnictwo Państwowego Muzeum Oświęcim-Brzezinka, 2008, s. 57.

${ }^{3}$ Wśród nich wyróżnia się Wilhelm Brasse, którego oświadczenia stanowią główne źródło informacji o działalności Erkennungdienst. Brasse, jako więzień o numerze 3444 i zarazem fotograf obozowy, w latach 1941-1943 wykonał 40-50 tys. zdjęć, które sam nazywa „policyjnymi. Były to klisze o wymiarach $6 \times 12,5 \mathrm{~cm}$, na których robiono trzy fotografie jednego więźnia: pierwsze ujęcie trzy czwarte w nakryciu głowy, następnie en face i z profilu. Brasse fotografował więźniów od początku 1941 aż do połowy $1943 \mathrm{r}$.

${ }^{4}$ APMAB, Oświadczenia, t. 3, Relacja Wilhelma Brassego z 14 VI 1959 r., k. 377, oraz ibidem, t. 19, Relacja Bronisława Jureczka, k. 112. Jureczek także był pracownikiem zakładu fotograficznego.
} 
ko w obiegu instytucjonalnym (jako ważna część muzealnych ekspozycji, ilustracje w podręcznikach, albumach), lecz także indywidualnym - przez byłych więźniów, których publikowane wspomnienia, jeśli to możliwe, chętnie ilustrowane są tą właśnie fotografią ${ }^{5}$. Powszechna obecność tych zdjęć i oczywistość związana z ich używaniem jako ikonicznych ilustracji rzadko pociąga za sobą refleksję dotyczącą sposobu, zasadności i celu ich powstawania. Fotografia jako medium z gruntu nowoczesne, uznawane za „obiektywizujące”, „dokumentalne” i mechanicznie rejestrujące, zdaje się niewidoczne, $z$ łatwością poddawane jest naturalizacji, która utrudnia stawianie pytań, mogących ten pozornie oczywisty porządek podważyć. Przy głębszej refleksji okazuje się, że z punktu widzenia fotograficznego medium i dotychczasowych sposobów jego używania (zarówno tworzenia, jak i późniejszego obiegu), fotografia, może przede wszystkim właśnie ta identyfikacyjna, użyta w kontekście Zagłady i późniejszych praktyk pamięci, wydaje się wyjątkowo nieoczywista, a sposób jej stosowania szczególnie problematyczny.

Mam tu na myśli, po pierwsze, narzucającą się analogię między fotografowaniem i zabijaniem. To, że aparat fotograficzny i karabin mają ze sobą coś wspólnego, było już przedmiotem licznych interpretacji - filozoficznych, artystycznych i popkulturowych. Susan Sontag w swojej klasycznej książce $O$ fotografii napisała: „Podobnie jak aparat fotograficzny jest sublimacją broni, robienie komuś zdjęcia stanowi sublimację morderstwa - łagodnego morderstwa, pasującego do naszych smutnych, pełnych strachu czasów"6. Tak jak w rzeczywistości Auschwitz nie istniało „łagodne morderstwo”, tak aparat nie był „sublimacją” karabinu, ale jego antycypacją. Ten, kto był fotografowany, od momentu zrobienia zdjęcia zostawał wchłonięty przez machinę obozową, tożsamą ze śmiercią.

Po drugie, tym, co uderza w kontekście zdjęć identyfikacyjnych wykonanych w Auschwitz, jest nie tylko sposób ich powstawania, ale ich zaskakujący brak. Chodzi tu nie tylko o brak dosłowny, wynikający z tego, że uratowane 38000 negatywów to tylko niewielka część wszystkich wykonanych fotografii identyfikacyjnych. Również ich funkcjonowanie dzisiaj wiąże się z pojęciem braku - swoją obecnością przywołują zdjęcia, które nigdy nie powstały: przedstawiające setki tysięcy osób, w znacznej większości Żydów, nigdy niezarejestrowanych w obozowych kartotekach, prosto z rampy kierowanych do komór gazowych i tam mordowanych.

${ }^{5}$ Przykładem mogą być wydane w 2011 r. wspomnienia Władysława Bartoszewskiego Mój Auschwitz (Kraków: Znak) - na okładce książki widnieje jedno z trzech zdjęć, jakie wykonano Bartoszewskiemu w trakcie rejestracji w obozie. Innym zjawiskiem są kierowane do Archiwum Państwowego Muzeum Auschwitz-Birkenau prośby byłych więźniów o przekazanie odbitki lub kopii obozowej fotografii.

${ }^{6}$ Susan Sontag, O fotografii, tłum. Sławomir Magala, Warszawa: Wydawnictwa Artystyczne i Filmowe, 1986. 


\section{Władek}

W dwóch tomach komiksu Maus Arta Spiegelmana ${ }^{7}$, niemal w całości rysowanego czarno-białą, charakterystyczną kreską, pojawiają się trzy fotografie. Nieprzypadkowe, umieszczone w znaczących miejscach, swoją obecnością poruszają kwestie reprezentacji oraz pamięci - kategorie nieodłącznie związane $\mathrm{z}$ medium fotograficznym.

Pierwsze zdjęcie, które znajduje się w połowie pierwszego tomu Maus, przedstawia kilkuletniego Arta w towarzystwie mamy na plaży. Drugie zdjęcie, na początku drugiego tomu, ukazuje chłopca, któremu dedykowana jest ta część komiksu - Rysia, pierwszego syna Władka i Mali, który zginął, mając kilka lat. Ostatnie zdjęcie, zamykające drugi tom, nie tylko dopełnia obrazu rozbitej pomiędzy trzy fotografie rodziny, ale zaskakuje.

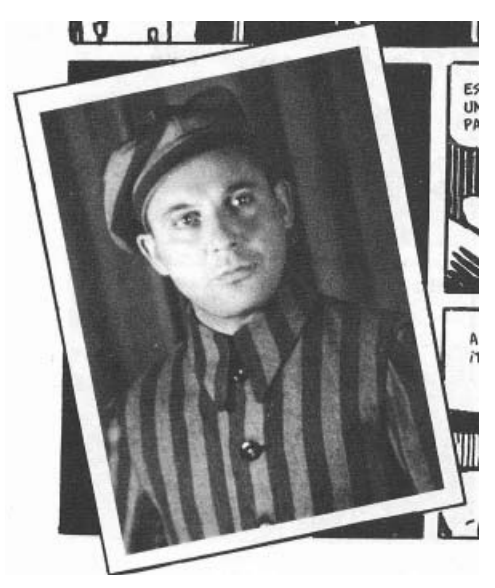

Fotografia przedstawia Władka niedługo po zakończeniu wojny: na konwencjonalnym portrecie studyjnym widzimy młodego, dobrze wyglądającego, poważnego człowieka ubranego w pasiak - strój więźnia obozu koncentracyjnego, którym jak wiemy z kontekstu opowieści, Władek był. „To wygląda tak, jakby on się nieźle bawił podczas robienia tego zdjęcia - wygląda na radosnego, ale w jakiś dziwny sposób. To kłopotliwa fotografia" mówi Art Spiegelman o zdjęciu swojego ojca. Analizujący Maus Dominick LaCapra również zauważa: „Biorąc pod uwagę jego doświadczenie Holokaustu, Władek jest wciąż uderzająco, właściwie - szokująco, przystojny, ubrany w wytwornie wykonany obozowy pasiak, który założył, nad wyraz entuzjastycznie się prezentując”8. Wrażenie dziwności, nieprzystawalności to efekt niemal groteskowego kontrastu formy i treści. Forma to bowiem tradycyjny portret fotograficzny - skomponowany jako popiersie, klasycznie oświetlający połowę twarzy modela, któremu fotograf poleca skierować wzrok lekko do góry i w lewo; z ciężką, pofałdowaną kotarą w tle, tak charakterystyczną dla przed- i tużpowojennych zakładów fotograficznych. Tym, co szokuje, jest połączenie konwencji ze znaczeniem wyłaniającym się nie z tego, co widzimy, a raczej z tego, co wiemy - oto uświadamiamy sobie, że patrzymy na b y ł e g o więźnia nazistowskiego obozu koncentracyjnego, który p o z u j e w pasiaku. Nasuwający się ciąg skojarzeń (pasiak - obóz - Zagłada

\footnotetext{
${ }^{7}$ Art Spiegelman, Maus. Opowieść ocalałego, t. 1: Mój ojciec krwawi historia, t. 2: I tu się zaczęty moje kłopoty, tłum. Piotr Bikont, Kraków: Post, 2001.

${ }^{8}$ Dominick LaCapra, History and Memory after Auschwitz, Ithaca-London: Cornell University Press, 1998, s. 156.
} 
- śmierć) okazuje się nietrafiony, bo patrząc na zdjęcie Władka, patrzymy na człowieka p r z e b r a n e g o - kogoś, kto założył pasiak na specjalną okazję, jaką jest wizyta u fotografa i wykonanie okolicznościowego portretu; kto nosił pasiak wcześniej, bo był do tego zmuszony. Teraz zaś, niedługo po ocaleniu i odzyskaniu wolności, zdecydował się założyć go ponownie. W dodatku utrwalił ten gest i obraz - siebie w pasiaku - w profesjonalnym studiu fotograficznym.

Pierwsze pytanie, które rodzi się w obliczu takiej fotografii, brzmi: po co? Pojawienie się fotografii w komiksie jest poprzedzone opowieścią o rozdzieleniu Władka z Andzią, ukochaną - po zakończeniu wojny nie mieli o sobie wieści, szukali się. Andzia odwiedziła wróżkę, która powiedziała jej: „On wraca do domu. Jak będzie pełnia, dostaniesz z n a k, że on żyje”. Tym znakiem był list i fotografia - właśnie ta, przedstawiająca Władka w obozowym pasiaku, ale na tle kotary zdradzającej fotograficzne atelier. Andzia, gdy otwiera list, wykrzykuje: „A tutaj jego z d jęc i e! Mój Boże - Władek żyje naprawdę!”. Władek, opowiadając tę historię Artowi, tłumaczy: „Przechodziłem raz koło fotografa. Mieli tam p a s i a k - nowy i czysty - do pa mi ą t k o w y ch zdjęć... Andzia zawsze przechowywała to zdjęcie. Mam je wciąż w biurku”".

Jest więc prawdopodobne, że zdjęcie zostało użyte jako dowód życia ${ }^{10}$. Nie wiemy jednak, dlaczego Władek zdecydował się skorzystać z pasiaka dostępnego w fotograficznym studiu - czy chciał pamiętać swoją obozową przeszłość? Czy chciał ją oswoić, pokazać innym, włączyć do swojej osobistej biografii?

To trudne pytanie jest tylko jednym $z$ wielu, jakie ta fotografia stawia. Spotkanie z nią może być przykładem tego, co Roland Barthes w swojej klasycznej książce Swiatło obrazu nazywa doświadczeniem punctum zdjęcia - owym ukłuciem sprawiającym, że dane zdjęcie ma w sobie siłę wynikającą z tego, co autor nazywa tym-co-było - czasem obecnym w zdjęciu; czasem, który w wypadku zdjęcia Władka kłuje najbardziej, bo uświadamia, że to, co widzimy, dzieje się już p o, że wbrew pozorom i pierwszym skojarzeniom, jest czasem życia (czy p r z e-życia), a nie czasem śmierci. To z kolei wywołuje pokusę poddania się iluzji, w której „wszystko dobrze się skończyło". Jest jednak inaczej - pojedyncza historia, której portret mamy przed sobą, przez swój kontekst pozostaje związana z brakiem innych portretów. Widzimy tylko jedną twarz na tle kotary, za którą znajduje się sześć milionów innych.

\section{Kolejne fotografie}

Zdjęcie Władka Spiegelmana stało się pretekstem do poszukiwania podobnych. Odszukałam kilkanaście fotografii - różnorodnych, pochodzących z rozmaitych

${ }^{9}$ Spiegelman, Maus..., t. 2, s. 134.

${ }^{10}$ Marianne Hirsh przywołuje opowieść o swojej krewnej Friedzie Wolfinger, która również poinformowała swoją rodzinę o tym, że ocalała z Zagłady, za pomocą zdjęcia wysłanego pocztą. Marianne Hirsh, Family Frames: Photography, Narrative and Postmemory, Cambridge, MA: Harvard University Press, 2002, s. 18. 
źródeł, dość przypadkowo odkrywanych ${ }^{11}$. Łączy je kilka powtarzalnych elementów: przedstawiają byłych więźniów nazistowskich obozów koncentracyjnych; są portretami wykonanymi w studiu fotograficznym ${ }^{12}$; powstały niedługo po zakończeniu wojny (w latach 1945-1947); pokazują osoby ubrane w pasiak obozowy.

Te cechy definiują wybrane zdjęcia jako podobne na tyle, że uznaję je za pewien typ i analizuję wspólnie jako dowód pewnego szerszego zjawiska, którego skala jest mi, niestety, nieznana. Kilkanaście zdjęć to zbyt mało, aby formułować precyzyjne wnioski dotyczące charakteru jakiejkolwiek fotograficznej praktyki, ale wystarczająco dużo, aby - także na podstawie ich różnorodności - sądzić, że było to zjawisko, jeśli nie popularne, to jednak powtarzalne i jako takie zasługujące na próbę interpretacji.

Zdjęcia, które będę omawiać, można podzielić na trzy podstawowe grupy, które nawet w tak skromnej próbie tego rodzaju fotografii dają się łatwo wyodrębnić.

Pierwsza z nich to zdjęcia pojedyncze, „rozproszone”, wykonywane w różnych miejscach, w różnych momentach, przedstawiające ludzi, których nie łączą jakiekolwiek relacje. Druga grupa zdjęć skupia różne osoby, ale sfotografowane w niemal identyczny sposób - to pięciu chłopców z grupy „dzieci z Buchenwaldu”13, których łączą rodzinne bądź przyjacielskie więzy, a których zdjęcia powstały w tym samym czasie i miejscu. Trzecia grupa przedstawia tę samą osobę, ale sfotografowaną na kilka odmiennych sposobów. To Josef Szlajfsztajn - chłopiec, który trafił do obozu w Buchenwaldzie w wieku niecałych czterech lat wraz ze swoim ojcem.

\section{Zdjęcia rozproszone ${ }^{14}$}

David Bajer

Zdjęcie nr 45509 ze zbiorów Muzeum Pamięci Holokaustu w Waszyngtonie, podpisane: „Portretowe zdjęcie Davida Bajera w kurtce od więźniarskiego uniformu, wykonane niedługo po wyzwoleniu”, zostało zrobione w 1945 r. w Kozienicach. Przedstawia urodzonego w 1922 r. Żyda, mieszkańca Kozienic, który podczas wojny trafił najpierw do getta, potem do kilku kolejnych obozów pracy, a w lipcu 1944 r. został deportowany do Auschwitz-Birkenau. Podczas ewakuacji obozu w styczniu 1945 r. został wyprowadzony z innymi więźniami w marszu śmierci i trafił do obozu Blechhammer, z którego uciekł wraz z dwoma sowieckimi jeńcami. Niedługo po zakończeniu wojny na krótko wrócił do Kozienic - wtedy

${ }^{11}$ Zdjęcia, które są przedmiotem analizy w tym artykule, pochodzą w większości z archiwum fotografii Amerykańskiego Muzeum Pamięci Holokaustu w Waszyngtonie, reszta to efekt przeszukiwania zasobów internetu oraz literatury.

${ }^{12}$ Wyjątkiem są niektóre zdjęcia Josefa Szlajfsztajna.

${ }^{13}$ Por. Judith Hemmendinger, Robert Krell, The Children of Buchenwald: Child Survivors and Their Post-War Lives, Jerusalem: Gefen Books, 2000.

${ }^{14}$ Wszystkie opisy zdjęć pochodzących ze zbiorów Muzeum Pamięci Holokaustu zostały zredagowane na podstawie informacji dostępnych w katalogu archiwum fotografii znajdującego się na stronie internetowej muzeum: http://digitalassets.ushmm.org/photoarchives/. 


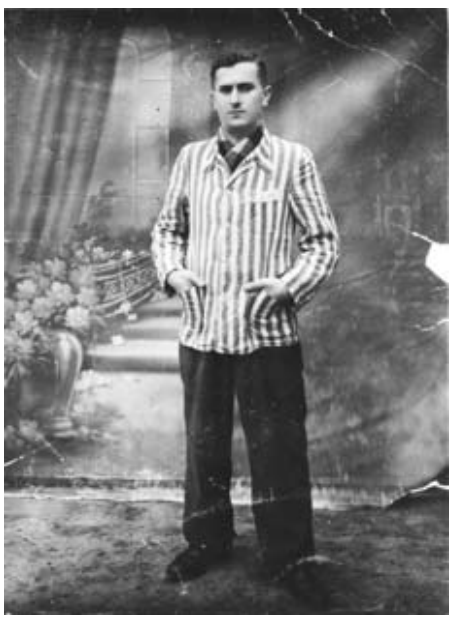

zostało wykonane zdjęcie - po czym wyjechał na Zachód. Mieszkał w Stanach Zjednoczonych i Panamie. Stamtąd wyjechał do Izraela, skąd szybko powrócił, aby w 1955 r. na stałe osiąść w Stanach.

Jest to jedyne zdjęcie wykonane na charakterystycznym dla małomiasteczkowych, przedwojennych zakładów fotograficznych tle $^{15}$. Połączenie kiczowatej estetyki z nonszalancką postawą i bluzą od obozowego pasiaka przypomina żart, dowcipną stylizację, której sens leży w zmieszaniu ze sobą kompletnie różnych porządków: rzeczywistości przed Zagładą (tło), rzeczywistości Zagłady (pasiak) i rzeczywistości po Zagładzie (były więzień). Wrażenie wzmacniają wygląd i postawa portretowanego, które w żadnym stopniu nie pasują do wyobrażenia o kimś, kto właśnie wyszedł z obozu. Dlatego pasiasta kurtka, jaką nosi - zaskakująco dobrze dopasowana - w połączeniu ze zwykłymi spodniami, półbutami i bardzo starannie założonym szalikiem, wygląda jak rekwizyt pochodzący z zupełnie innej, teatralno-groteskowej rzeczywistości.

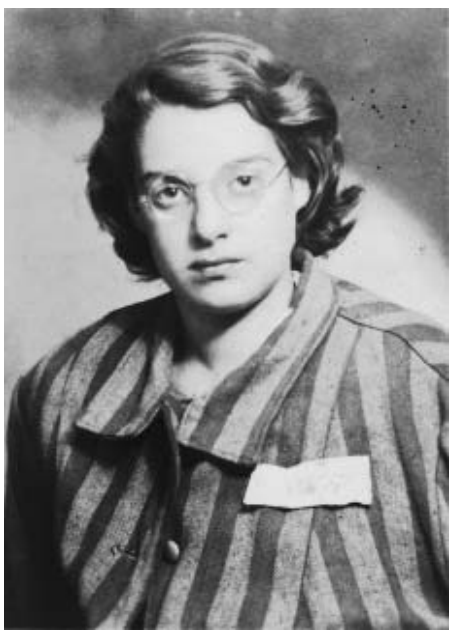

\section{Agnes Laszlo}

Zdjęcie nr 61033 w zbiorach Muzeum Pamięci Holokaustu w Waszyngtonie to „Portret Agnes Laszlo wykonany niebawem po jej wyzwoleniu”, datowany na 1945 r., zrobiony w Innsbrucku. Z załączonego opisu wynika, że Agnes urodziła się w 1930 r. w Budapeszcie. Wraz z matką i siostrami została deportowana do Auschwitz w połowie lipca 1944 r. Stamtąd, wraz z innymi węgierskimi Żydówkami, zostały wysłane do pracy w fabryce samolotów w Calw koło Stuttgartu. Idąc w marszu śmierci w kierunku Mauthausen, doczekały wyzwolenia przez wojska amerykańskie w kwietniu 1945 r. Po uwolnieniu Agnes wraz z siostrami i matką przez osiem miesięcy mieszkała w Innsbrucku - w tym czasie wykonane zostało zdjęcie. Później wróciły na Węgry, skąd w 1949 r. przez Marsylię wyjechały do Izraela.

${ }^{15}$ Iwona Kurz, Fotografia $w$ przedwojennym miasteczku, komputeropis udostępniony przez autorkę. 


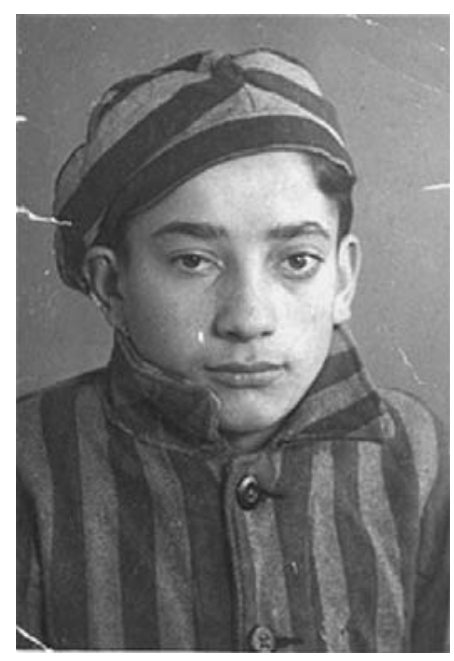

Alexander Feuer

Zdjęcie nr 02109 ze zbiorów Muzeum Pamięci Holokaustu w Waszyngtonie jest zatytułowane „Portret donatora, Alexandra Feuera, w jego dawnym uniformie więziennym”. Zostało wykonane w czerwcu 1947 r. w Memmingen w Niemczech. Alexander Feuer, podobnie jak Agnes Laszlo, był Węgrem. Urodził się w 1929 r. w miejscowości Satu Mare. Po kilku miesiącach pobytu w getcie, w maju 1944 r. deportowano go do Auschwitz, skąd w sierpniu został wysłany do Niemiec. Tam przez kilka miesięcy był przenoszony z obozu do obozu, aby ostatecznie doczekać wyzwolenia w Turkheim. Trafił do Memmingen, gdzie zostało wykonane zdjęcie, po czym został umieszczony w prowadzonym przez UNRRA domu dla dzieci w Chiemsee. Pozostał tam do września 1947 r., kiedy to wyemigrował do Stanów Zjednoczonych.

Ta fotografia, jako jedna $z$ nielicznych, przedstawia portretowaną osobę pozującą do zdjęcia w swoim własnym pasiaku. Jest to o tyle istotne, że zdjęcie Alexandra zostało wykonane aż dwa lata po wyzwoleniu - wyklucza to możliwość, że założenie pasiaka do zdjęcia wynikało na przykład z braku cywilnego ubrania. Prawdopodobnie Feuer zachował swój pasiak, a decyzja o sfotografowaniu się w nim była decyzją świadomą, zaplanowaną i nieprzypadkową.

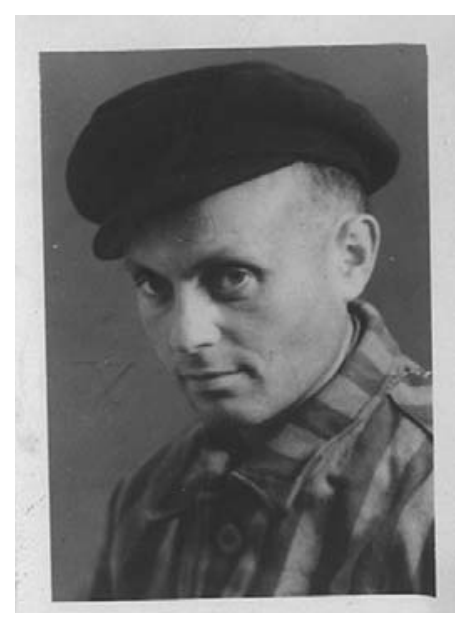

\section{Chaim Weiser}

Zdjęcie Chaima Weisera nie pochodzi z oficjalnego archiwum, lecz z artykułu One Generation to Another: Reflections from the Child of Holocaust Survivors ${ }^{16}$, opublikowanego w internecie. W dziale zatytułowanym „Secrets of Dead” znajduje się artykuł i wywiad z Leonną Wreschner - córką Chaima i Rachel Weiserów, austriackich Żydów ocalałych z Zagłady. W wywiadzie poznajemy relację córki, która tuż po śmierci swoich rodziców rekonstruuje ich doświadczenia oraz doświadczenie swoje, jako dziecka dziedziczącego traumę.

${ }^{16}$ Zob. http://www.pbs.org/wnet/secrets/escape-from-auschwitz/one-generation-to-another-reflections-from-the-child-of-holocaust-survivors (dostęp 4 VIII 2012 r.). 


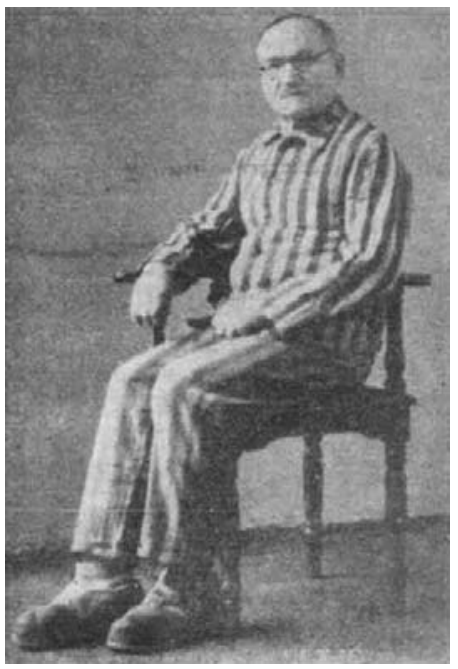

Maksymilian Basista

Zdjęcie Maksymiliana Basisty znajduje się w publikacji Żotnierze rybnickiego ZWZ/AK, POP, PTOP w obozach koncentracyjnych ${ }^{17}$. Publikacja w porządku alfabetycznym przedstawia sylwetki byłych więźniów, często opatrzone zdjęciami - przed- lub powojennymi. Przy opisie Maksymiliana Basisty - rybnickiego księgarza i społecznika - znalazła się ta fotografia, opatrzona następującym przypisem:

Informacja dodatkowa. Gdy zbliżały się do Oświęcimia wojska rosyjskie (a więc pod koniec funkcjonowania KL Auschwitz), władze SS niszczyły dowody zbrodni popełnionych na więźniach, niszczono także dokumenty obozowe. Skutkiem tego nie było śladu pobytu w tym obozie Maksymiliana Basisty. Autor niniejszego opracowania dostarczył do APMA-B ${ }^{18}$ wiarygodne informacje na ten temat - w oparciu o zdobyte zeznania świadków. Zdjęcie w ubraniu obozowym nie jest typowym zdjęciem wykonywanym w obozie, lecz wykonanym na własny użytek przez Maksymiliana Basistę po powrocie do domu ${ }^{19}$.

Opis ten, rekonstruujący kontekst zdjęcia, zasługuje na szczególną uwagę - przedstawia fotografię w roli dowodu, potwierdzenia. Po pierwsze, tkwi w nim sugestia, że gdyby wśród ocalałych dokumentów znalazło się zdjęcie Basisty, nie byłyby niezbędne szczególne starania potwierdzające jego status jego więźnia. Po drugie, jest rodzajem sprostowania, że opublikowane zdjęcie nie jest zdjęciem obozowym - uznano widocznie, że istnieje niebezpieczeństwo zbudowania fałszywego przekonania na temat rzeczywistości obozowej. Z opisu dowiadujemy się, że powstało „na własny użytek Maksymiliana Basisty, po powrocie do domu”. Basista nie otrzymał po wojnie, jak niektórzy byli więźniowie, swojego obozowego zdjęcia identyfikacyjnego, nie miał więc ani pamiątki, ani dowodu legitymizującego jego status jako byłego więźnia. Wykonał je dla siebie, na potrzeby - być może - swojego rodzinnego albumu.

\section{Salvator Moshe}

Salvator Moshe był greckim Żydem urodzonym w Salonikach w 1915 r. Na początku 1943 r. wraz z całą rodziną został przetransportowany do Auschwitz.

${ }^{17}$ Jerzy Klistała, Żotnierze rybnickiego ZWZ/AK, POP, PTOP w obozach koncentracyjnych: Auschwitz-Birkenau, Mauthausen, Gusen, Dachau, Ravensbrück, Buchenwald, Majdanek, Oranienurg, Sachsenhausen, Flossenburg i innych, Bielsko-Biała: Wydawnictwo „Prasa Beskidzka", 2008.

${ }^{18}$ Archiwum Państwowego Muzeum Auschwitz-Birkenau.

${ }^{19}$ Klistała, Żotnierze rybnickiego ZWZ/AK..., s. 25-26. 

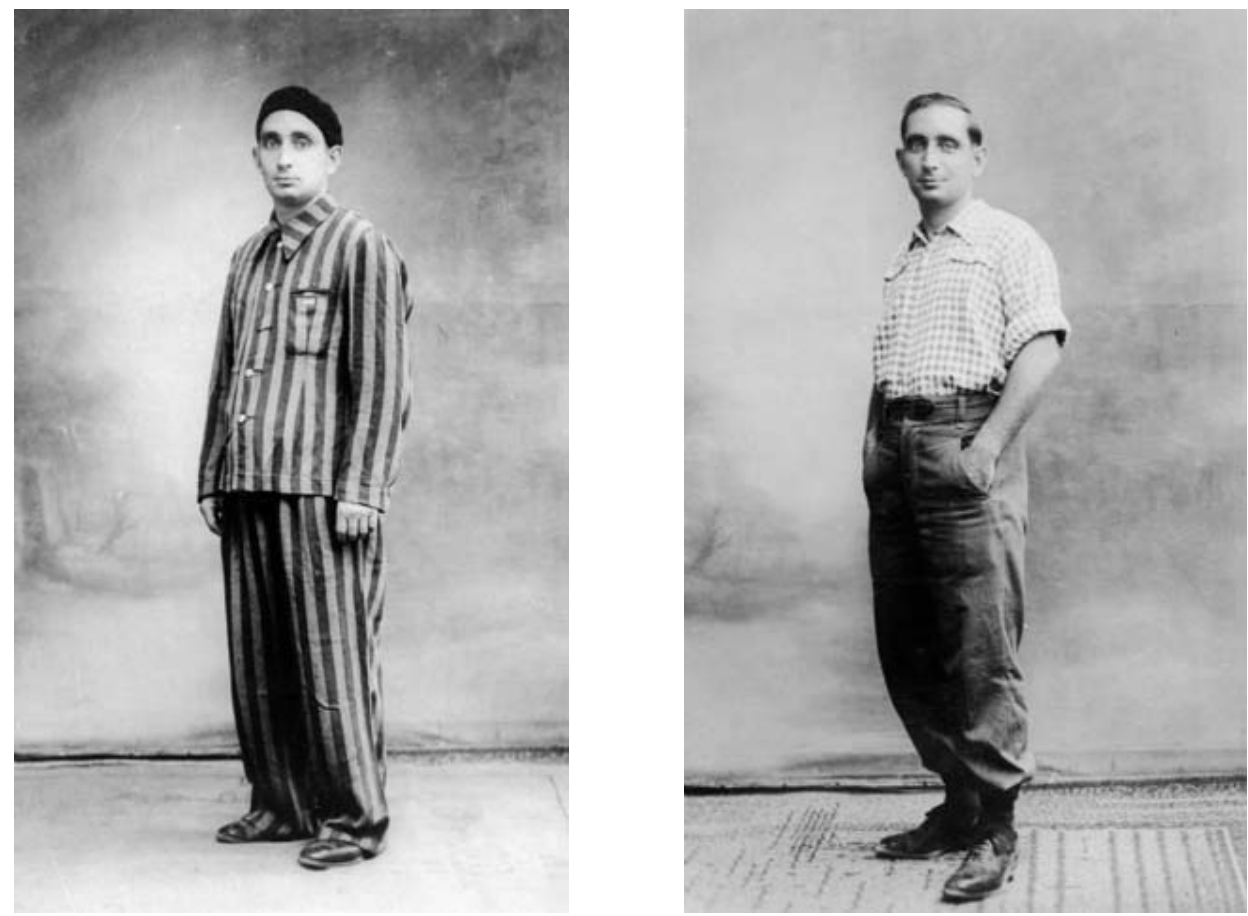

Stamtąd trafił do Warszawy, gdzie pracował przy oczyszczaniu zniszczonego getta warszawskiego. Wyzwolenia doczekał w Dachau.

Pierwsze zdjęcie jest oznaczone numerem 56899 i podpisane: „Portret Salvatora Moshe w pożyczonym ubraniu obozowym (beret należał do niego)”20. Data wykonania to 1945 r., a miejsce - Weilheim w Niemczech. Drugie, w ubraniu cywilnym, ma numer 56900 i nosi tytuł „Salvator Moshe w koszuli wykonanej z prześcieradła pożyczonego od niemieckiej kobiety” - data i miejsce takie same.

Prezentuję je razem, gdyż wydaje mi się niemal pewne, że powstały podczas tej samej wizyty w studiu fotograficznym i jako takie tworzą zestaw. Istotny jest nacisk położony na pochodzenie poszczególnych ubrań. Pasiak został pożyczony na potrzeby zdjęcia, ale informacja o nakryciu głowy, które należy do Moshego, potwierdza jego tożsamość jako byłego więźnia. Wspólne zdjęciom są kadr, oświetlenie, podłoga i tło (jest to z pewnością ten sam zakład fotograficzny), a moment wykonania zdjęć różni prawdopodobnie tylko czas konieczny do przebrania się. Mimo to bohater zdjęć prezentuje dwa skrajnie różne wizerunki - podkreślone nie tylko strojem, lecz także postawą ciała, grymasem.

${ }^{20}$ Oba zdjęcia pochodzą ze zbiorów Wisconsin Historical Society. Por. http://www.wisconsinhistory.org/whi/feature/holocaust/ (dostęp 4 VIII 2012 r.). 


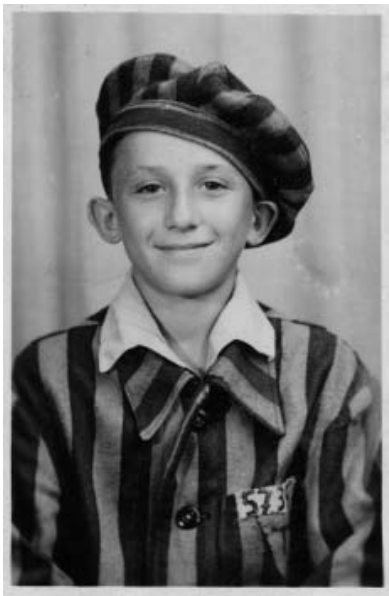

Heniek Kaliksztajn

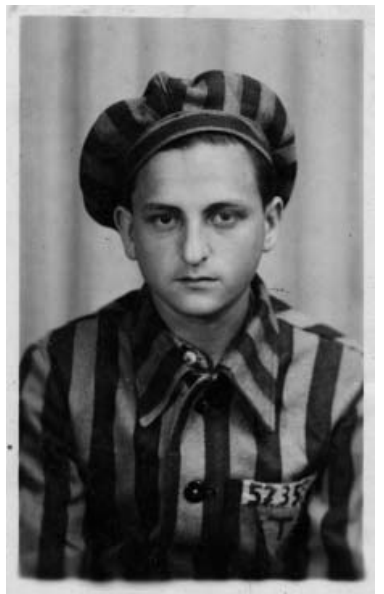

Zelig

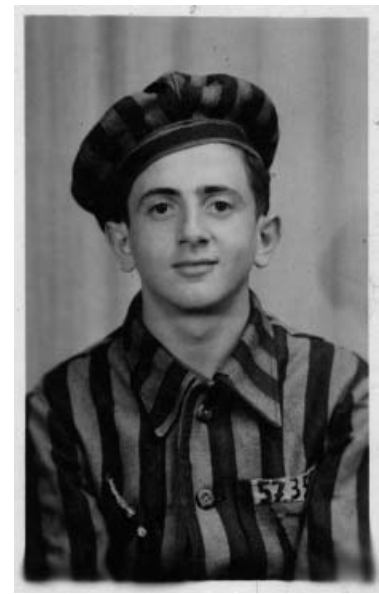

Benek

Chłopcy z Buchenwaldu (wszystkie zdjęcia ze zbiorów Muzeum Pamięci Holokaustu w Waszyngtonie)

Heniek Kaliksztajn, urodził się w 1931 r. w Strzemieszycach. Zdjęcie nr 28966, opatrzone podpisem: „Portret studyjny ocalonego z Buchenwaldu, Heńka Kaliksztajna, w więźniarskim uniformie”, wykonane zostało w lipcu 1945 r. w Ambloy we Francji. Zdjęcie ma na odwrocie dedykację: „Dla mojego przyjaciela Berka”.

Zelig - dokładne imię i nazwisko ani data i miejsce urodzenia nie są znane. Zdjęcie nr 29026, podpisane: „Portret studyjny byłego więźnia Buchenwaldu, Zeliga, w więźniarskim uniformie”. Wykonane zostało w 1945 r. w Ambloy we Francji. Zdjęcie nosi dedykację: „dla mojego drogiego przyjaciela Berka”. Dodatkowo przy zdjęciu zawarta jest informacja, że pasiak, w którym sfotografował się Zelig, należał do Mozesa Kuznitza (nr 57356), urodzonego w 1926 r. w Syhocie (Sighet) w Rumunii.

Benek $^{21}$, najprawdopodobniej Bernard Rybsztajn, brat Jakoba, kolega Heńka Kaliksztajna, urodził się w 1929 r. w Strzemieszycach. Zdjęcie nr 29058, podpisane: „Portret studyjny byłego więźnia Buchenwaldu, Benka, w więźniarskim uniformie”, zostało wykonane 27 lipca 1945 r. w Amboly we Francji. Najprawdopodobniej to właśnie jemu były dedykowane dwa wyżej opisane zdjęcia.

Jakob Rybsztajn (Jacques Ribons), brat Benka i kolega Heńka Kaliksztajna, urodził się w 1927 r. w Strzemieszycach.

${ }^{21} \mathrm{~W}$ podpisach zdjęć znajdujących się na stronie internetowej Muzeum Pamięci Holokaustu pojawia się nieścisłość dotycząca skróconej wersji imienia Bernerda Rybsztajna - zamiennie występuje „Benek” i „Berek”. Być może jest to spowodowane trudnością w odczytaniu odręcznych dedykacji umieszczonych na odwrocie zdjęć - litera „r” pisana odręcznie łatwo może zostać odczytana jako „n” i odwrotnie. 


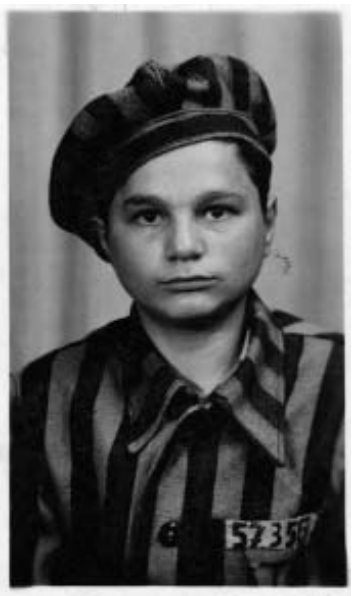

Jakob Rybsztajn

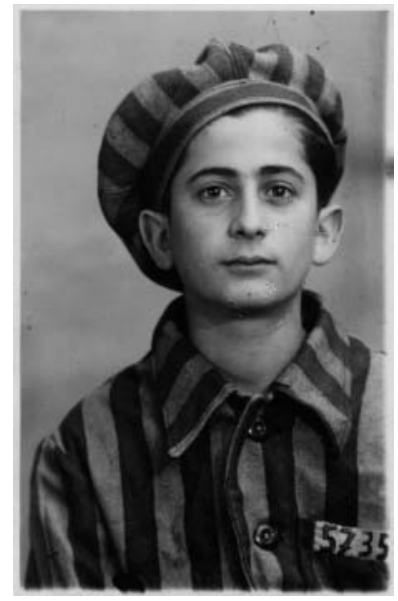

Ludwig Grunberger

Zdjęcie nr 29049, podpisane: „Portret studyjny byłego więźnia Buchenwaldu w więźniarskim uniformie" - brak podpisu dotyczącego daty oraz miejsca wykonania. Przy tej fotografii, podobnie jak przy zdjęciu Zeliga, pojawia się taka sama informacja odnośnie do pochodzenia pasiaka.

Ludwig Grunberger urodził się w 1928 r. w Użhorodzie na Rusi Podkarpackiej (wówczas w Czechosłowacji, w czasie okupacji tereny te należały do Węgier). Zdjęcie nr 29093, podpisane: „Portret studyjny byłego więźnia Buchenwaldu, Ludwiga Grunbergera, w więźniarskim uniformie”, zostało wykonane w 1945 r., nie podano miejsca.

Ze zdjęć oraz opisów wyłania się opowieść: żydowscy chłopcy, dwaj bracia Jakob i Bernard Rybsztajnowie ze Strzemieszyc wraz ze swoim kolegą Heńkiem Kaliksztajnem, trafili w 1943 r. do getta w Będzinie, stamtąd do Blechhammer, aż w końcu w lutym 1945 r., w marszu śmierci do Buchenwaldu. Tam zostali umieszczeni w bloku dziecięcym nr 66, kierowanym przez Gustava Schillera, gdzie znajdowało się już około tysiąca dzieci pochodzenia żydowskiego. Po wyzwoleniu trafili do domu dziecka w Ambloy we Francji - właśnie w tym czasie wszyscy wykonali sobie zdjęcia. Potem, jak większość „dzieci z Buchenwaldu”, zostali adoptowani lub samodzielnie wyemigrowali, głównie do Francji, Szwajcarii, Anglii oraz Stanów Zjednoczonych.

Mimo różnic $\mathrm{w}$ podpisach pod poszczególnymi zdjęciami możemy być pewni, że wszystkie powstały podczas jednej wizyty w studiu fotograficznym w Ambloy, najprawdopodobniej 27 lipca 1945 r. Tym, co ewidentnie łączy te fotografie, jest pasiak oznaczony numerem 57356, podobny wiek wszystkich chłopców oraz ich wspólna historia. W zakładzie fotograficznym najwyraźniej fotografowali się po kolei, zdejmując i zakładając to samo ubranie. Wątpliwe, aby zdjęcia powstały z jakichkolwiek powodów instytucjonalnych - użycie pasiaka (i to tego samego) wydaje się temu przeczyć. Dwie dedykacje sugerują, że wykonali zdjęcia dla siebie nawzajem - Zelig i Heniek podarowali swoje zdjęcia Benkowi. Nie wiemy, czy były to jedyne odbitki ani czy inni także wymienili się nimi „na pamiątkę”. 


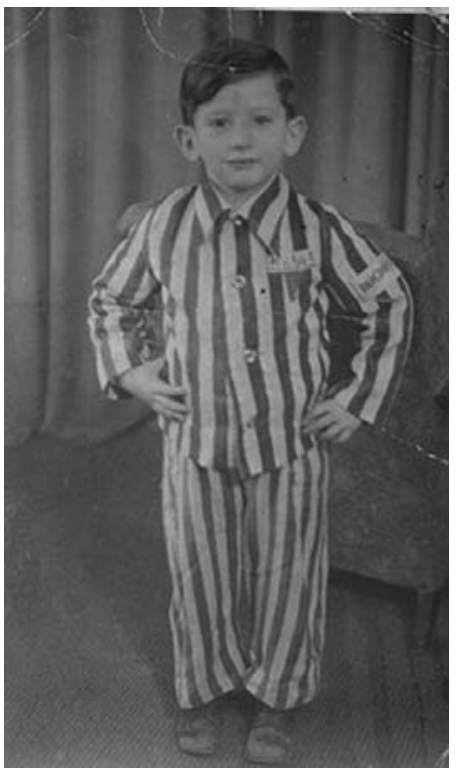

Josef Schlajfsztajn (wszystkie zdjęcia pochodza ze zbiorów Muzeum Pamięci Holokaustu $w$ Waszyngtonie)

Josef Szlajfsztajn urodził się 7 marca $1941 \mathrm{r}$. w Sandomierzu. Jego rodzice aż do końca 1944 r. pracowali w obozach pracy na terenie Generalnego Gubernatorstwa. W tym czasie Josef przebywał w ukryciu. Dopiero w styczniu 1945 r. matka, Esther, została zesłana do Bergen-Belsen, a ojciec, Izrael, do Buchenwaldu. Podczas selekcji Izrael przemycił Josefa wówczas niespełna czteroletniego - w skórzanej torbie na narzędzia. Chłopiec szybko został odkryty przez SS i, co zadziwiające, zaczął być traktowany jak obozowa maskotka. Po wyzwoleniu obozu Izrael wraz z synem odnaleźli Esther. Zamieszkali w Dachau, skąd w 1947 r. wyemigrowali do Stanów Zjednoczonych. Zdjęcie jest oznaczone numerem 09557 oraz podpisane: „Portret Josefa Szlajfsztajna ubranego w swoje ubranie obozowe, rok lub dwa po wyzwoleniu". Zostało wykonane około 1946 r. w Dachau. W archiwum muzeum znajdują się także inne zdjęcia przedstawiające Josefa, między innymi:

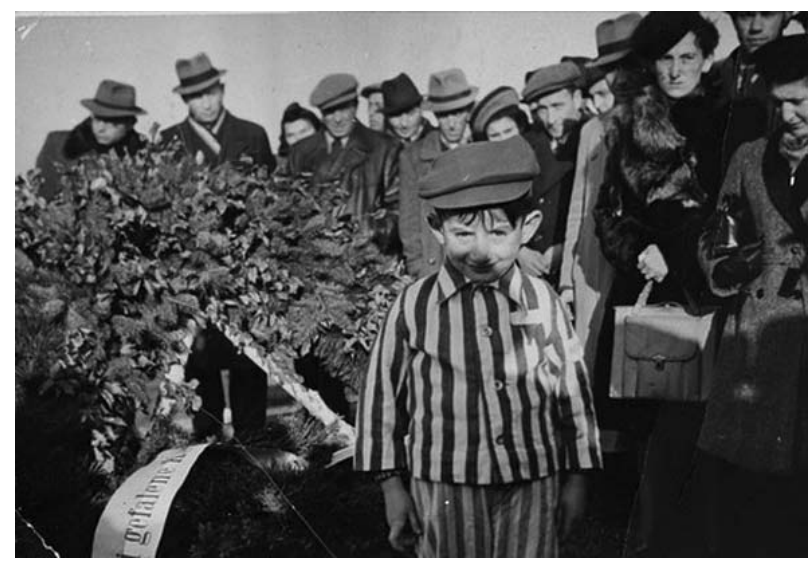

Zdjęcie nr 09558, „Ubrany w swój dawny pasiak, żydowski chtopiec Josef Szlajfsztajn, podczas mszy upamiętniajacej w Buchenwaldzie", wykonane okoto $1946 r$.

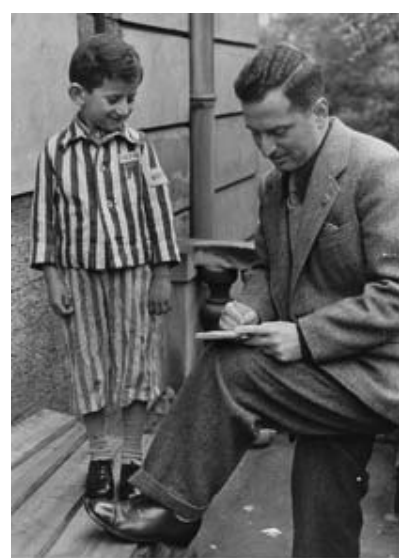

Zdjęcie nr 07230, „Josef Szlajfsztajn, ubrany w swój stary pasiak z Buchenwaldu, udziela wywiadu dziennikarzowi", wykonane okoto 1946 r. w Dachau. 
Zdjęcia przedstawiające Josefa Szlajfsztajna w wielu aspektach różnią się od zdjęć prezentowanych wcześniej. Portretowany chłopiec ma zaledwie sześć lat i decyzja o wykonaniu zdjęcia w pasiaku z pewnością nie należała do niego. Po drugie zaś, niektóre zdjęcia sugerują, że Josef stał się w pewnym sensie osobą publiczną - wciąż odgrywał rolę maskotki, ale już w innych rękach. Widzimy go, gdy w przykusym pasiaku udziela wywiadu dziennikarzowi oraz w trakcie ceremonii upamiętniającej ofiary Buchenwaldu. Jako jedyny ubrany jest w pasiak. Dodatkowo, symboliczną rolę Josefa podkreśla inne zdjęcie, wykonane bez pasiaka - chłopiec, po wyzwoleniu obozu, szybko został przebrany przez wojska alianckie w miniaturowy mundur wojsk amerykańskich, stając się tym samym swoistym symbolem pozwalającym manifestować zwycięstwo.

\section{Portret}

Omawiane zdjęcia to klasyczne portrety - reprezentują technikę i estetykę charakterystyczną dla studyjnych zdjęć z lat trzydziestych (utrzymującą się również później). Portret jako gatunek wpłynął na sposób używania fotografii w codziennym życiu, a przez to na jej rolę w sposobie definiowania tożsamości jednostki, jej stosunku do swojej świadomości, pamięci i ciała ${ }^{22}$. Fotografowanie stało się pewnego rodzaju rytuałem dokumentowania węzłowych momentów w biografii jednostki. Zdjęcia wykonywane „z okazji”, w określonej sytuacji (często w atelier fotograficznym), stroju, towarzystwie i pozycji - ze względu na zakładaną „obiektywność” medium - obdarzano dużym znaczeniem, kluczowym dla konstruowanej na podstawie albumu fotograficznego autonarracji. Jednocześnie dostępność i szybkość powstawania fotografii pozwalały ten wizerunek wciąż aktualizować, „aktualizować się” (self-actualization) wraz z nim²3. Liczne zabiegi służyły przygotowaniu się do zdjęcia (a potem jego obróbce), aby to, co fotografowane, pasowało do wizualnej narracji rodzinnego albumu. Ta estetyka „idealizowanego dokumentu”, kreującego rodzinną czy osobistą biografię, odpowiadała porządkowi świata, w którym jednostki miały określone normami biografie, znane, pochodzące z zamkniętego zbioru role.

Historia portretu fotograficznego i jego gatunków to historia dynamicznie zmieniającej się proporcji między podkreślaniem indywidualności portretowanej osoby

${ }^{22}$ Celia Lury w publikacji Prosthetic Culture wybiera właśnie fotografię jako medium, które chce analizować przez pryzmat jego związku z tożsamością. Uważa, że o ile na temat związku tożsamości z narracją słowną napisano już wiele, o tyle o związku tożsamości z obrazem wciąż niewystarczająco, pomimo podejmowania rozległych badań dotyczących nowoczesności, którą charakteryzuje dominujące znaczenie technik wizualnych. Lury podejmuje to wyzwanie i stawia w swojej książce pytanie o to, jaki wpływ może mieć obraz fotograficzny - a dokładniej portret - na nowatorskie kształtowanie tożsamości, samowiedzy i prawdy. Por. Celia Lury, Prosthetic Culture. Photography, Memory and Identity, London-New York: Routledge, 2005, s. 41-42.

${ }^{23}$ Ibidem, s. 11. 
a wkładaniem jej w społeczne i kulturowe ramy zapewniające poczucie przynależności.

Fotografia - narzędzie zapewniające ludziom swoistą ochronę przed lękiem, z jednej strony bywa dokumentem, potwierdzającym tożsamość jednostki, z drugiej zaś - potwierdza przynależność człowieka do danej zbiorowości. Fotografie opisują i dokumentują tożsamość rodziny, grupy zawodowej, pokoleniowej czy towarzyskiej24

- pisze Iwona Kurz w tekście, w którym wprowadza pojęcie fototożsamości. Wykorzystując sztafaż gotowych i społecznie akceptowanych konwencji, portret ma siłę nadawania jednostce wyraźnej, odwołującej się do zewnętrznych i obiektywnych czynników tożsamości publicznej - moc nadawania komunikatu. „Fotografia, szczególnie portretowa, ma tę cechę, że definiuje człowieka jako jednostkę, typ jednostki, jako gatunek" 25 - w wypadku omawianych zdjęć jest to o tyle kłopotliwe, że dotychczas nie istniał „gatunek” „ocalonego/ocalonej z Zagłady” czy „byłego więźnia/byłej więźniarki obozu koncentracyjnego”. Zagłada oznaczała przełamanie milionów pojedynczych biografii - dla wielu zakończonych tragiczną śmiercią, dla ocalałych zaś wyzwanie powrotu do życia. Osobiste narracje nie mogły zostać podjęte w miejscu, w którym zostały brutalnie przerwane - wymagały nowego rozpoczęcia, bez możliwości nawiązania do przeszłego porządku, zarówno osobistego, jak i społeczno-politycznego ${ }^{26}$. Patrząc na omawiane portrety, obserwujemy więc próbę skonstruowania nowego "gatunku”, nowego typu „roli” w zbiorze zdjęć, które wydają się w sposób wyjątkowy naznaczone piętnem indywidualnego doświadczenia - niepodobnego do niczego, co wydarzyło się wcześniej.

O ile fotografia portretowa może więc służyć wzmacnianiu przynależności lub podkreślaniu odrębności, o tyle w rzeczywistości pozagładowej przynależenie gdziekolwiek nie było oczywiste, konwencje zdezaktualizowały się, a zbiorowości, z którymi można byłoby się utożsamić, uległy kryzysowi, rozproszeniu lub zniszczeniu. W kontrze do koncepcji fotografii jako znaku przynależności Marianna Michałowska pisze: „żeby rozpoznać własną tożsamość w obrazie, należałoby znaleźć w nim znamię samego siebie, ową bliznę, która dotyczy tylko mojej osoby i nikogo innego" 27 . To koncepcja użycia fotografii nie tylko do rozpoznania się jako „będącego podobnym”, lecz właśnie do wyodrębnienia siebie jako wyjątkowego, do „bycia jedynym” - ale za cenę „znamienia”, „blizny”.

${ }^{24}$ Iwona Kurz, Fototożsamość. „Ja” w czasach fotografii, „Kultura Współczesna” 2006, nr 4, s. 87-88.

${ }^{25}$ Lury, Prosthetic Culture..., s. 41.

${ }^{26}$ Maria Orwid pisze wręcz, że przystosowanie się byłych więźniów do życia po wyzwoleniu było w pewnym sensie trudniejsze od życia w obozie. Por. Maria Orwid, Trauma, Kraków: Wydawnictwo Literackie, 2009, s. 127.

${ }^{27}$ Marianna Michałowska, Obraz utajony. Szkice o fotografii i pamięci, Kraków: Galeria f5 \& Księgarnia Fotograficzna, 2007, s. 35. 
Wracając do fotografii portretowej jako popularnego rytuału dokumentującego węzłowe momenty biografii, proponuję przyjrzenie się omawianym zdjęciom jako wykonywanym na pamiątkę wydarzenia traumatycznego, w znaczeniu ściśle osobistym; jako zdjęciom powstającym w czasie naznaczonym silnym, wszechobecnym b r a k i e m. Ich rola w konstruowaniu - czy raczej odbudowywaniu - podmiotowości sfotografowanych osób, choć związana z portretem fotograficznym od dawna, wydaje się wyjątkowa.

\section{Trauma}

„[...] ludzie ocaleni z obozu są inni” Maria Orwid ${ }^{28}$

Wszyscy bohaterowie omawianych przeze mnie zdjęć są Żydami; wszyscy przeszli przez obozy koncentracyjne - bez względu na to, jaką pozycję zajmowali w obozowej hierarchii, pewne jest, że doświadczyli odwróconej logiki systemu, który negował ich prawo do życia. To indywidualne doświadczenie traumy - ze względu na totalny i precedensowy charakter Zagłady - w pewnym sensie stało się także doświadczeniem zbiorowym, ponadjednostkowym. Pisał o nim między innymi Imre Kértesz:

Dziś już wiadomo, że doświadczenie Holokaustu to nie tylko osobista sprawa tych, którzy przetrwali; długi, mroczny cień Holokaustu kładzie się na całej naszej cywilizacji, w której musimy nadal żyć obarczeni ciężarem i następstwami wydarzeń z przeszłości ${ }^{29}$.

Charakter traumy jako binarnej - z jednej strony indywidualnej, z drugiej zaś wspólnej ogółowi ludzkość, wskazuje analogię z opisanymi właściwościami portretu fotograficznego, odpowiadającego potrzebom indywidualnym, ale czerpiącym z konwencji zbiorowych i publicznych.

„[...] Trauma jako sekretna rana zapewnia podstawę ekspresji odrębności jednostki, ustanawianej w procesie samobadania, konfrontacji, odkrywania, uleczania i przetrwania”30 - pisze Lury. „Uleczenie”, wedle klasycznej koncepcji, miało polegać na powtórzeniu doświadczenia w formie opowieści słownej - włączeniu tego, co traumatyczne w symboliczny porządek języka. Proponuję w zamian pomyśleć o porządku obrazowym - porządku fotograficznych autoportretów. Pomysł ten wynika ze znaczenia wizualności, która w ponowoczesnej rzeczywistości zyskała silniejszą niż kiedykolwiek wcześniej pozycję. Wiąże się z nią przywołane już pojęcie fototożsamości - „foto-ja, delegowanego w świat widzialności po to,

\footnotetext{
${ }^{28}$ Orwid, Trauma, s. 116.

${ }^{29}$ Imre Kértesz, Język na wygnaniu, tłum. Ewa Sobolewska, Warszawa: W.A.B., 2004,

${ }^{30}$ Lury, Prosthetic Culture..., s. 12.
} s. 67. 
by choć na chwilę dać wytchnienie płynnej i niepewnej tożsamości, bezustannie dążącej do scalenia"31.

Fotografię charakteryzuje umiejętność dystansowania, zapośredniczenia doświadczeń, które w obrazowej formie mogą wydawać się ujarzmione. Potrzebę przedstawienia sobie tego, co się przeżyło, podkreśla Georges Didi-Huberman, opisując rolę, jaką dla grupy byłych więźniów odegrało obejrzenie fotografii zrobionych w obozach podczas Zagłady ${ }^{32}$. Pisze on również o przypadku byłego więźnia Auschwitz, dla którego dokumentalne obrazy Zagłady były przez długi czas obojętne - nie potrafił rozpoznać w nich swojego własnego doświadczenia, do momentu gdy jeden z obrazów pozwolił wniknać w przywołany w nim czas: „[z]upełnie jakby w pewnej chwili akt stawienia czoła obrazowi okazał się konieczny do przyjęcia samego faktu przez psychikę ocalałego"33. Poza dystansem i spojrzeniem na samego/samą siebie fotografię charakteryzuje także czasowość dająca możliwość wykreowania sytuacji powtórzenia - odpowiadająca w pewnym stopniu czasowości i potrzebie repetycji przynależnych traumie. Agata Bielik-Robson teorię traumy wyprowadza z krytyki narracyjnej koncepcji tożsamości ${ }^{34}$. Autorka zwraca uwagę, że model funkcjonujący od czasów filozofii kantowskiej zakłada zbawienną funkcję czasu dla kształtowania podmiotu, który w nim istnieje, konstytuuje się i potwierdza. Według Bielik-Robson to jednak właśnie czas jest traumą - tym, co zawsze przychodzi za wcześnie, wobec czego rozumienie zawsze nadchodzi za późno. To oznacza, że podmiot zderza się z niekontrolowaną, zaskakującą i niejasną temporalnością, wobec której jest zawsze w niedoczasie. Ta pierwsza, rzeczywista trauma jest tą, z którą „ja” nie jest w stanie sobie poradzić. Dlatego konieczne jest powtórzenie, które - jako to drugie, zaplanowane w czasie - daje szansę na naprawienie tej pierwszej, rzeczywistej szkody.

Skoro traumatyzujące spotkanie z rzeczywistym nie utrwala się w postaci wyraźnego znaku, a jedynie uobecnia zawsze później w powtórzeniu, które dopiero wtedy nadaje temu powtórzeniu charakter znakowy, symboliczny, to nie ma żadnego powodu, aby nastawać na pierwotność owej traumy: repetycja jest czymś pierwszym, bo dopiero dzięki niej spotkanie to może zaistnieć dla psyche ${ }^{35}$.

\footnotetext{
${ }^{31}$ Kurz, Fototożsamość..., s. 21.

32 „[...] odnalezienie wizualnych dokumentów - filmów czy zdjęć - przez ocalałych z obozów odegrało istotną rolę w zaakceptowaniu przez nich własnych doświadczeń, tzn. w ukonstytuowaniu się ich pamięci. Musieli przedstawić sobie to, co przeżyli, chociażby po to, aby o tym zaświadczyć”. Georges Didi-Huberman, Obrazy mimo wszystko, s. 109.

${ }^{33}$ Ibidem, s. 110.

${ }^{34}$ Agata Bielik-Robson, Stowo i trauma: czas, narracja, tożsamość, „Teksty Drugie” 2004, nr 5, s. 23-34.

${ }^{35}$ Jacques Derrida, Freud i scena pisma [w:] idem, Pismo i różnica, tłum. Krzysztof Kłosiński, Warszawa: Wydawnictwo KR, 2004, cyt. za: Bielik-Robson, Stowo i trauma...,
} s. 32 . 
Spotkanie w tym ujęciu, zapośredniczone przez obraz fotograficzny, umożliwia spojrzenie na siebie przez gest powtórzenia, ponowne uobecnienie, ale także utrwalenie tego obrazu - zatrzymanie $\mathrm{czasu}^{36}$, próbę odzyskania nad nim kontroli.

\section{Gest}

[...] kwestia możliwości pochwycenia przez fotografię tego, co realne, a więc niejako schwytania przedmiotu $\mathrm{w}$ chwili fotografowania, jest zgłębiana w oparciu o portret: należy zastapić frazę t o - c o - b y ł o wyrażeniem t o - co - z o s t a ło - o d e gra n e $\mathrm{e}^{37}$

- pisze François Soulages, zwracając uwagę na nieodłączny związek fotografii z możliwością inscenizacji i teatralizacji. Teatralność fotografii w potocznym znaczeniu może kojarzyć się z rodzajem sztuczności, udawania. Swoistość omawianych zdjęć polega jednak między innymi na tym, że aktor jest swoim reżyserem - sam dobiera scenariusz i rekwizyty. To sprawia, że (wbrew temu, co dalej proponuje Soulages) za pośrednictwem fotografii, nawet w ramach jej klasycznych konwencji, może dokonywać się i spełniać wolny, autorski akt twórczy. Rola, grana przed obiektywem, nie musi być narzucona - może zostać wybrana, dowolnie powtórzona. Osoby, które oglądamy na zdjęciach, są „byłymi więźniami”, „ocalonymi z Zagłady” - ich naznaczona traumą i narzucona tożsamość jest bezpośrednim następstwem procesu instytucjonalnego włączenia w obozowe struktury. Dlatego ponowne odegranie tej roli - siebie jako „byłego więźnia”, „ofiary”, „ocalonego” - które realizuje się w dobrowolnym geście założenia pasiaka, staje się gestem odzyskania prawa do kształtowania swojej indywidualnej tożsamości zgodnie $z$ dokonywanymi wyborami ${ }^{38}$.

Zwracam uwagę, że to gest właśnie - poprzedzający powstanie fotograficznego obrazu - wydaje się w tej koncepcji najistotniejszy. Gest, co istotne, wykonywany przez osobę mającą konkretne ciało. O jego znaczeniu jako jednego z elementów fundującego tożsamość (obok pamięci i świadomości) pisała cytowana już Celia Lury - pojęcie embodiment oznacza u niej wcielenie, czyli zdolność osoby do rozpoznawania siebie jako mającej jednostkowe, unikatowe ciało. Rozpoznanie to jest osiągane przez różne techniki wizualnej klasyfikacji, w tym, jak twierdzi Lury, przez portret fotograficzny - zaadaptowaną „protezę”, pozwalającą ukonstytuować tożsamość, która nie jest już definiowana przez stwierdzenie „myślę, więc

${ }^{36}$ Por. André Bazin, Ontologia obrazu fotograficznego [w:] idem, Film i rzeczywistość, tłum. Barbara Michałek, Warszawa: WAiF, 1963, cyt. za: Tomasz Ferenc, Fotografia. Dyletanci, amatorzy i artyści, Łódź: Galeria F5 \& Księgarnia Fotograficzna, 2004, s. 45-46.

${ }^{37}$ François Soulages, Od przedmiotu portretu do ogólnego przedmiotu fotografii: „to, co zostało odegrane" [w:] idem, Estetyka fotografii. Strata i zysk, tłum. Beata Mtych-Forajter, Wacław Forajter, Kraków: Universitas, 2007, s. 67-86.

${ }^{38} \mathrm{O}$ projekcie tożsamości jako nieodłącznie związanej z wyborem i możliwością jego kontroli pisze obszernie Anthony Giddens. Por. idem, Nowoczesność i tożsamość, tłum. Alina Szulżycka, Warszawa: Wydawnictwo Naukowe PWN, 2007, s. 261, 292-293, 306. 
jestem”, ale przez „mogę, więc jestem”; a skoro „mogę” - to działam. W koncepcji Lury zakładany jest potencjał kreowania relacji pomiędzy świadomością, pamięcią i ciałem, który sprawia, że jednostka ma możliwość i prawo do tego, aby dowolnie i wielokrotnie składać i rozkładać swoją tożsamość. Obraz fotograficzny pełni funkcję jednej z technik umożliwiających przekształcanie konwencjonalnych układów relacji między tymi trzema elementami i potwierdzania ich przez zdolność do „wkładania w ramę, zamrażania i ustanawiania”"

W obozowym doświadczeniu prawo do rozporządzania swoim ciałem zostało zanegowane - odebranie go było jednym z podstawowych narzędzi podporządkowywania, łamania i wyniszczania więźniów. Powojenny, podjęty mimo wszystko gest posłużenia się ciałem w obliczu obiektywu fotograficznego, może więc być interpretowany jako ustanowienie „ciała odzyskanego”, gdyż decyzja o tym, aby pozować do zdjęcia w obozowym ubraniu, wymagała świadomego działania. To z kolei wyraźnie uwypukla istotny, choć rzadko wydobywany wymiar fotografii jako zdarzenia, którego sens i znaczenie leży w dokonanym wyborze. Zwykle kategoria ta bywa ograniczana do decyzji o tym, co pozostawić poza kadrem, a co w nim ująć - i jako taka leży po stronie fotografa. W wypadku omawianych fotografii jest inaczej: wybór, który nadaje im znaczenie, nie jest związany ze standardowym, centralnym kadrem czy klasycznym, studyjnym oświetleniem. Rola fotografa została tutaj sprowadzona do roli rzemieślnika wykonującego jedynie wizję fotografowanego, który używa siebie, swojego ciała i możliwości utrwalenia jego wizerunku jako narzędzi służących konkretnemu, choć niekoniecznie uświadomionemu (lub możliwemu do zrekonstruowania) celowi. Wchodząc w rolę i dokumentując siebie w tej roli, zyskuje on kontrolę nad jej znaczeniem - dokonuje klasycznego powtórzenia, a nawet powtórnego odegrania, wykorzystując do tego praktykę fotograficzną.

Prowadzi to do najistotniejszego według mnie rozpoznania - kontekst, w jakim powstawały portrety ocalonych, sprawia, że sens i znaczenie tych fotografii leży nie tyle w zarejestrowanym obrazie, ile w performatywnym geście założenia pasiaka. To gest stworzenia siebie jako naznaczonego doświadczeniem - więźnia, ofiarę, ocalonego.

\section{Obraz odzyskany}

„Utrzymać obraz siebie to znaczy «ochronić swoje ja», w psychicznym i społecznym tego słowa znaczeniu”.

Georges Didi-Huberman ${ }^{40}$

Portrety fotograficzne wykonane przez byłych więźniów obozów koncentracyjnych tuż po Zagładzie są podwójnym świadectwem: po pierwsze, są obrazem przeżycia, dowodem ocalenia; po drugie, są o b r a z e m od z y s k a n y m, obrazem

\footnotetext{
${ }^{39}$ Por. Lury, Prosthetic Culture..., s. 1-40.

${ }^{40}$ Didi-Huberman, Obrazy mimo wszystko, s. 57.
} 
świadczącym o decyzji konfrontacji z własnym, traumatycznym doświadczeniem, stawiającym przed koniecznością spojrzenia na siebie i swoją bliznę jako całość. To efekt próby skonstruowania siebie jako ocalonego (wobec wszystkich tych, którzy zginęli) oraz jako ofiary - postawionej przed koniecznością przywrócenia sobie prawa do życia, a co za tym idzie, oswojenia braku.

Poruszając problematykę etyki obrazów, Didi-Huberman pisał o sytuacji nieustannego rozłamu przynależnego podwójnemu porządkowi obrazu - o tym, że nie jest on ani wszystkim, ani niczym. Obraz nie jest również ani śmiercią (reprezentowaną przez zdjęcia identyfikacyjne i implikowany przez nie brak), ani życiem (uratowanym, ocalonym). Istnieją jednak takie sytuacje lub praktyki, które sprawiaja, że zaczyna on ciążyć ku jednej z tych dwu szal - nie dlatego, że sam zaburza swoją wewnętrzną, dialektyczną równowagę, ale dlatego, że zostaje ona przez k o g o ś naruszona, kogoś świadomie bądź nie wykorzystującego w swoich działaniach jego niestałą i niejednoznaczną konstrukcję. To nie obraz poddawać więc można etycznej ocenie, lecz najwyżej tego, kto się nim posługuje.

Ta niejednoznaczność, bez względu na usilną próbę narzucania obiektywizacji, właściwa jest fotografii od samych jej początków. Nigdy dotychczas jednak sposoby jej używania nie były doprowadzone do takiej skrajności, jaką możemy obserwować w praktykach związanych z Zagładą - w czasie jej trwania i później. Metaforyczna lub dosłowna śmierć obecna w fotografii nigdy nie oznaczała śmierci sześciu milionów ludzi, a widok życia, które trwa, nigdy nie był tak wyjątkowy. Mimo tego doświadczenia fotografia nie została naruszona czy zaprzeczona. Skoro została użyta w ten sposób, oznacza to, że takie użycie było możliwe. Zarówno z perspektywy działania mechanizmu, praktyki, jak i obiegu samych fotografii nie zdarzyło się nic, co miałoby je uniemożliwić. Po raz kolejny ujawniony został potencjał fotografii jako narzędzia podatnego na spełnianie określonych celów, problematyzowanego przez swoich własnych użytkowników. Nie zmieniła się więc istota fotografii, a raczej skala jej doświadczenia, hiperbolizującego dotychczasowe jej użycia.

\title{
Słowa kluczowe
}

fotografia identyfikacyjna, fotografia portretowa, Auschwitz, trauma, Maus, pasiak

\begin{abstract}
The identification photographs of Auschwitz-Birkenau prisoners are a Holocaust icon. Photography, particularly identification photography, seems especially ambiguous in the context of the Holocaust, and the manner in which it was used and then conceptualized seems especially problematic. The remnants of the postwar photographic practice of former concentration camp prisoners are all the more puzzling: some of them had their photographs taken in concentration camp stripes in professional photo studios. Some dozen photos taken during 1945-1947 show survivors who decided to record their images as ex-prisoners. By doing so they referred to the prewar portrait photography tradition and repeated the gesture of putting on
\end{abstract}


concentration camp outfits and (perhaps) the experience of being photographed in the camp. Compared with the practice of taking identification photographs, the portraits turn out to be a material whose interpretation problematizes the issue of radically different ways of using photography as an institutional tool of oppression on the one hand and as a tool of individual confrontation with the traumatic experience on the other. The comparison of identification and portrait photographs is an occasion to reflect on the ways in which photography was used in the context of the Holocaust and at the same time on the condition of photography as a medium.

\section{Key words}

identification photography, portrait photography, Auschwitz, trauma, Maus, concentration camp stripes (pasiaki) 